\title{
Success Rate of Zygomatic Implants for Rehabilitation of Severely Atrophied Maxillae: A Review of the Literature
}

\author{
Tasa de Éxito de los Implantes Cigomáticos para la Rehabilitación \\ del Maxilar Severamente Atrofiado: Una Revisión de la Literatura
}

\author{
Felipe Alejandro Cid Cisternas* \& Bárbara Daniela Soto Neira**
}

CID, C. F. A. \& SOTO, N. B. D. Success rate of zygomatic implants for rehabilitation of severely atrophied maxillae: a Review of the Literature. Int. J. Med. Surg. Sci., 3(1):771-777, 2016.

SUMMARY: Severe resorption in the posterior maxilla sectors as a result of tooth loss along with the process of pneumatization of the maxillary sinus, difficult the prosthetic rehabilitation supported by conventional implants due to the shortage of vertical bone availability. So that over the years they have designed therapeutic alternatives to help overcome these drawbacks. The zygomatic implant was introduced in 1988 by Branemark. This implant has a design which allows it to be positioned over the ridge to the height of the first molar, reducing vestibular cantilever up to $20 \%$ and reducing complications of peri-implant inflammation, infection and gingival hyperplasia, which may lead to perforation horizontal process of the palatine bone. The purpose of this review is to determine the success rate of zygomatic implants for rehabilitation of severely atrophied maxillae. A total of 1410 zygomatic implants and 1673 Traditional implants were included in selected articles. Of these 1410 zygomatic Implants, 365 were conventional loading and 1045 were immediately and early loading, these had a success rate of $98.3 \%$ and $98.7 \%$, respectively. Of these 1673 Traditional Implants, 463 were conventional loading and 1210 were immediately and early loading, they had a success rate of $93.9 \%$ and $97.8 \%$, respectively. The overall success rate of zygomatic implants and Conventional implants was $98.6 \%$ and $96.8 \%$, respectively. The rehabilitation of severely atrophied maxilla with fixed prosthesis immediately and conventional loaded by zygomatic implants gives excellent results in the medium term. When comparing traditional treatment modalities, proposals for prosthetic reconstruction of severely atrophied maxilla, the zygomatico implant has the highest success rate over conventional treatments.

KEY WORDS: Zygomatic implants; Success rate; Edentulous maxilla; Resorbed maxilla; Atrophied maxillae.

\section{INTRODUCTION}

Severe resorption of the maxilla in subsequent sectors as a result of tooth loss along with the process of pneumatization of the maxillary sinus, difficult the prosthetic rehabilitation supported by implants conventionally due to the shortage of vertical bone availability (Carvajal et al., 2009; Klurfan \& Klurfan, 2008; Malevez et al., 2004).

So that over the years they have designed therapeutic alternatives to help overcome these drawbacks. These therapeutic alternatives are represented by the (Carvajal et al.; Klurfan \& Klurfan; Balshi et al., 2009):
- Raising the maxillary sinus floor.

- Autologous Graft Block.

- Reconstruction of maxillary by surgery of iliac crest graft.

- Tilted implants in the anterior wall of the maxillary sinus.

- Le Fort I osteotomies with interpositional bone grafting.

- Implants in the pterygomaxillary region.

- Short implants with improved surfaces.

- Integration Platform Narrow.

- Combination of the above.

Of the Biomechanical prosthetic point of

* Odontología, Facultad de Ciencias de la Salud, Universidad Autónoma de Chile, sede Temuco, Chile.

** Odontología, Facultad de Odontología, Universidad Mayor, sede Temuco, Chile. 
view is important to have a posterior support implant, which prevent or restrict the prosthetic extensions in cantilevers and subsequent remote anchor in the zygomatic bone, decreases the prosthetic extension in cantilever and risks of moments sagittal torque (Carvajal et al.).

The zygomatic implant was introduced in 1988 by Branemark. This implant has a design of 30 to $52.5 \mathrm{~mm}$ long, $4 \mathrm{~mm}$ diameter apical in his two thirds and in the alveolar one third of $5 \mathrm{~mm}$ wide. The implant head presents an angle of $45^{\circ}$ and $55^{\circ}$, which allows it to be positioned over the ridge to the height of the first molar, anchoring in the zygomatic bone from the oral cavity through the maxillar bone, normally through in maxillar sinus (Carvajal et al.; Klurfan \& Klurfan; Degidi et al., 2012).

This implant allows us to reduce the vestibular cantilever up to $20 \%$ and reducing the complications peri-implant inflammation, infection and gingival hyperplasia, which may lead to perforation of the horizontal process of the palatine bone (Carvajal et al.).

The indications for placement of zygomatic implants are (Malevez et al.):

- Volume of sufficient bone in the anterior region of maxilla: the length of the upper arch with a height of $10 \mathrm{~mm}$ and a width of $4 \mathrm{~mm}$ allows placement 2-4 conventional implants, but the posterior resorption in the maxillary reduces the possibility of placement a standard implants.

- Insufficient bone volume in the anterior region of maxilla: the situation requires onlay bone graft or GBR for placement of conventional implants. The sinus graft to the posterior region could be contraindicated for clinical reasons or avoided by using zygomatic implants.

This type of rehabilitation can, if the premaxila is suitable for that matter, the insertion of 2, 4 or 6 conventional implants in the anterior maxilla, combined with 2 zygomatic implants or if the zygomatic bone anatomy allows us, We can install two bilateral zygomatic implants to restore a complete maxillary arch. If the anterior maxilla is too small, it is possible rehabilitations using 4 zygomatic implants, 2 on each side of the arch, one in the anterior area between the lateral incisor and the canine, and another at the back, between the second premolar and first molar (Carvajal et al.; Butura \& Galindo, 2012; Degidi et al.).

Treatment of resorption or atrophy of the posterior region maxilla is a challenge for the maxillofacial surgeon, implantologist and oral rehabilitation.

The purpose of this review is know the success rate of zygomatic implants for rehabilitation of severely atrophied maxillae.

\section{MATERIAL AND METHOD}

A search was conducted on the databases of EBSCOhost, ScienceDirect and PROQUEST. The key words used were Zygomatic implants, Success Rate, Edentulous maxilla, Resorbed maxilla \& Atrophied maxillae. Boolean terms: "AND" and "OR".

We include retrospective and prospective studies in humans, of both sexes, articles in which the patients were edentulous or partially edentulous where they received full arch rehabilitation with implant-supported prosthesis, with zygomatic implant in the posterior region and conventional implants in the anterior region in which they announced their success rate treatment, and follow-up of the treatment.

We do not include items that did not report their success rate in the treatment, where not detailed the methodology, literature reviews and animals models. 2013

Search limits were between the years 2000-

\section{RESULTS}

Three hundred thirty-three scientific articles were identified from the databases researched between the 2000 and 2013 year. We excluded studies by title and summary evaluation obtaining a total of 31 scientific articles. Subsequently an exclusion assessment was performed by full text, finally obtaining a total of 23 scientific papers. These studies were between in the 2003 and 2013 year. 


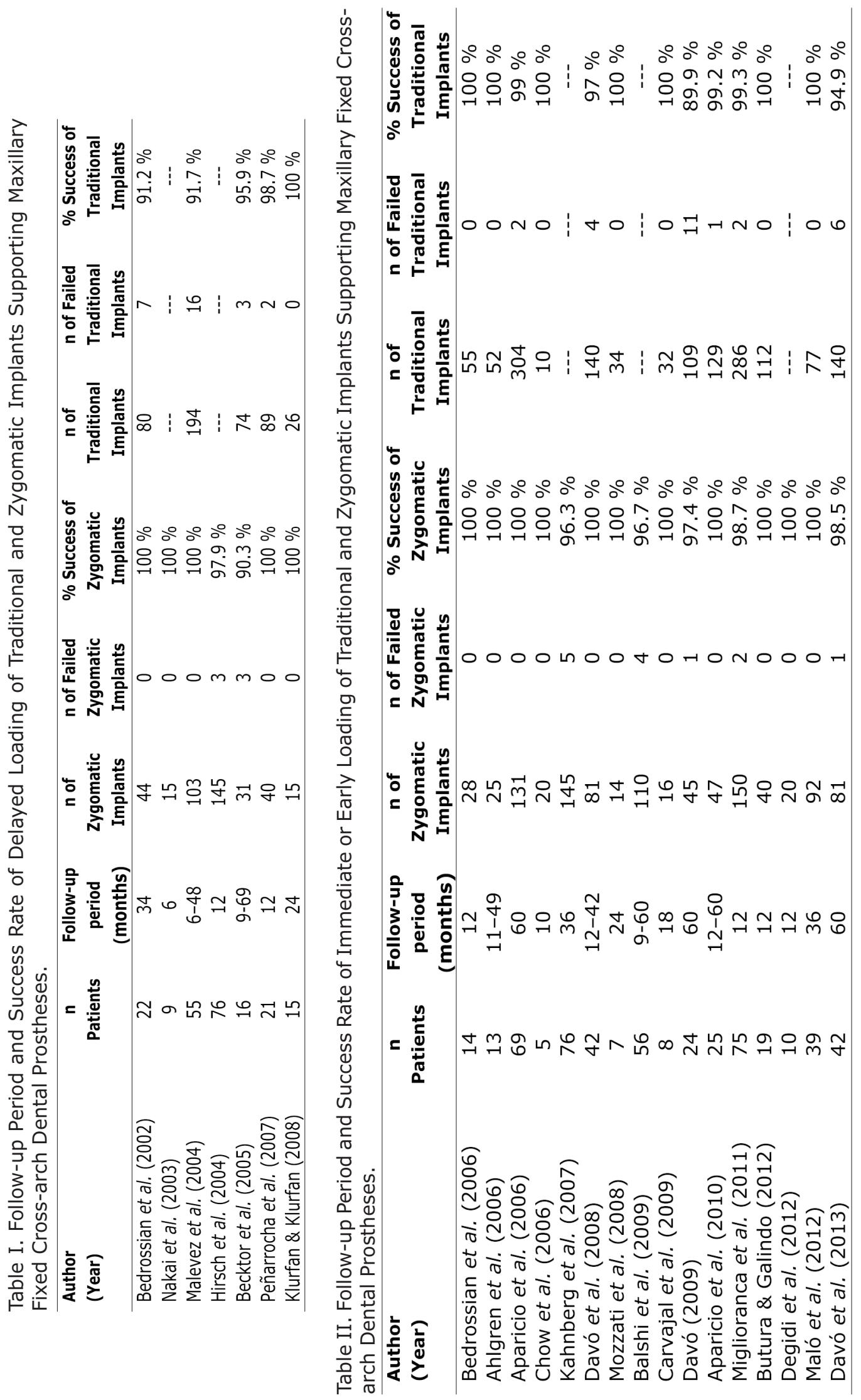

A total of 1410 zygomatic implants and 1673 Traditional implants were included in selected articles. Of these 1410 $\mathrm{z}$ y g o m a t i c Implants, 365 $w$ e $r$ e conventional loading and 1045 were immediately and early loading, these had a success rate of $98.3 \%$ and 98.7 $\%$, respectively. Of these 1673 Traditional Implants, 463 w e r e conventional loading and 1210 were immediately and early loading, they had a success rate of 93.9\% and $97.8 \%$, respectively. The overall success rate of zygomatic implants and Conventional implants was $98.6 \%$ and $96.8 \%$, respectively (Tables I and II). 


\section{DISCUSSION}

Inclusion and exclusion criteria of the patients before treatment (Carvajal et al.; Mozzati et al., 2008; Peñarrocha et al., 2007; Davó et al., 2013; Migliorança et al., 2011):

The inclusion criteria consisted of the following:

- The wearing of traditional complete maxillary dentures for at least 2 years prior to this intervention.

- The absence of severe systemic pathologies; no treatment with drugs.

- Clinical laboratory values compatible with implant surgery (complete blood count, blood glucose, coagulation time, sedimentation rate). - The absence of any kind of infection in the oral cavity or uncontrolled periodontal disease (in the case of presence of teeth in the mandible).

- No previous treated or untreated episodes of sinusitis, signs or symptoms of ongoing sinus inflammation or infection, or radiographically evident alterations of the sinus mucosa.

- The possibility of inserting 4 or 5 traditional implants in a premaxila with class A or B bone quantity.

- The possibility of inserting 2 zygomatic implants in a posterior maxilla with class $C$ or $D$ bone quantity.

- No signs of enamel crack, oclusal abrasions, masseter hypertrophy, bruxism, or alteration of the mandibular oclusal plane.

- The absence of a smoking habit.

The exclusion criteria consisted of the following: - Systemic pathology that contraindicated oral surgery implant installation.

- Smokers.

- Uncontrolled diabetes.

- Radiographic evidence of impaired sinus mucosa of the maxillary sinus.

Success criteria: In evaluating treatment outcome, the following implants success criteria were applied (Hirsch et al., 2004; Davó, 2009):

- No associated radiolucency.

- Absence of infection (including the maxillary sinus for zygomatic implants).
- Absence of soft tissue inflammation.

- Absence of pain.

- Absence of mobility.

- Functional loading of implants with a fixed prosthesis.

Complications reported in Zygomatic Implants: Hirsch et al. reported that the failures of 3 zygomatic fixtures were lost in 2 patients before prosthetic restoration. One patient lost both the zygomatic fixture and 1 patient had 1 remaining zygomatic fixture which was used as support for the prosthetic restoration. Excessive bleeding was reported in 3 patients in connection with implant surgery and 1 of these patients also developed a postoperative infection. Exposure of the zygomatic cover screw was reported for 1 patient.

Becktor et al. (2005) no founds records of any complications during the implant surgery, in the implant healing phase, or at the abutment connection surgery. After the abutment connection surgery, 10 of 16 patients had problems with oral hygiene at the zygomatic implant site. Mucositis was seen in nine patients; five of these patients presented with fistulae and local infection around their zygomatic implant, and four of these five patients had fistulae bilaterally. Local infection was treated with antibiotics and, in some cases, excision of the fistulae. Sinusitis was a problem for six patients. Three patients had sinusitis bilaterally and another three unilaterally. They were treated by an otolaryngology specialist with antibiotics and sinus rinses. Three patients had one zygomatic implants removed owing to infection in the maxillary sinus.

Aparicio et al. (2006) reported that three patients experienced acute sinusal infection after 14,23 , and 27 months postsurgery. One of them had a recurrent suppuration of the sinusal/nasal cavities. The infections could be cured by antibiotic treatment. Two of the three patients had been using an oral hygiene system based on highpressure water spraying. None of the zygomatic implants failed.

Davó recounts that during the follow-up period, one zygomatic implant was diagnosed as a failure and removed, but not replaced. This failure occurred in one of the drop-out patients with a complete arch rehabilitation, with two 
zygomatic implants and four conventional ones. Right after the placement of the implants, the patient started experiencing pain at the level of the right zygomatic, without swelling or any other symptoms. It was treated with antibiotic (amoxicillin/clavulanic acid 750/125 mg every 8 h) for 10 days, and analgesics for 1 month. The implant was then removed and the pain persisted for 2 more months. A neurologist did not find a clear explanation for the symptoms and the diagnosis was "atypical facial pain". Finally, the pain ceased and the patient was provided with an overdenture.

In the study of Migliorança et al. (2011), two zygomatic implants failed and were removed. None of the failed implants were replaced at this point. Two surviving zygomatic implants showed a soft tissue dehiscence in the cervical portion of the implant that reached approximately the level of the second thread of the implant; no sign of irritation or inflammation was observed around these two implants. No other soft tissue complications were observed in the other surviving zygomatic implants.

One zygomatic implant was lost in the study of Davó et al. (2013). The failed implant had a machined surface, and was found to be mobile after prosthesis removal at the 3-year follow-up, and was accompanied by disturbances in the zygomatic region. This case was diagnosed as implant failure; the implant was removed and not replaced. A slight bending movement was observed at 5 zygomatic implants: 3 implants out of 4 in 1 patient, and 2 implants in 1 patient having 2 zygomatic implants combined with 2 conventional implants. A macroscopic oroantral communication was found in a patient (a smoker) just after placement of an oxidized zygomatic implant. It was followed by an episode of sinusitis 4 month later. Sinusitis was successfully treated with amoxicillin/clavulanic ( $1 \mathrm{~g}$ every $8 \mathrm{~h}$ for 10 days) and meatotomy. The oroantral communication closed spontaneously 1 month later.

Complications reported in Conventional Implants: Peñarrocha et al. reported two implants failed: 1 anterior implant was lost 1 month after surgery due to periapical peri-implantitis, and the other (a pterygoid implant) failed at 2 months as a result of trauma with the complete prosthesis.
In the 2 patients in which implants failed, the definitive fixed screw-retained prostheses were supported by the remaining implants.

Aparicio et al. (2006) reported that one regular platform implant placed in the pterygoid process failed 1 month after abutment connection, previous to prostheses installation. One more regular implant failed after 27 months in function.

A total of 136 of the 140 conventional implants were stable in a study of Davó et al. (2008), patients experienced no pain and there were no radiolucent zones around the implants. One anterior implant in two patients and two in another patient were removed due to mobility at the 3-month recall. All provisional prostheses were stable.

In a study conducted in 2009 by Davó, reported that of the 109 originally installed conventional implants, 11 were considered failures and removed. These failures were distributed in six patients. Three patients lost one implant each at the day of the abutment connection. Four anterior implants were lost in the same patient at the abutment connection, while the zygomatic implants remained stable. Three additional implants were placed, but they failed again. Although, originally, an overdenture was designed using only two zygomatic implants, it was removed after 1 year to prevent further complications and the patient is now wearing a complete denture, as previously mentioned. The patient is currently waiting for a grafting procedure or two more zygomatic implants, whereas the originally installed zygomatic implants are stable.

Davó et al. (2013) reported that six conventional implants were lost in 4 patients. One anterior implant in 2 patients and 2 implants in another patient were removed due to mobility at the 3-month control visit. They were not replaced. Another anterior implant failed 4 years after placement in the same patient who lost the zygomatic implant. In this case, the conventional implant was replaced and immediately loaded and the definitive prosthesis changed to an overdenture. Another anterior implant failed at the 4 year follow-up in a patient with only 2 conventional implants, and was replaced and immediately loaded by adapting the definitive prosthesis. 


\section{CONCLUSION}

The rehabilitation of severely atrophied maxillae by prostheses fixed with implants early, immediately and conventional loading carried by zygomatic implants gives excellent results in the medium term.

When comparing traditional treatment modalities, proposals for prosthetic reconstruction of severely resorbed maxilla, the zygomatic implant has the highest success rate of treatments that conventional implants, $98.6 \%$ and $96.8 \%$, respectively.

More research is required for long periods of time to determine the best long-term success of this treatment.

CID, C. F. A. \& SOTO, N. B. D. Tasa de éxito de los implantes cigomáticos para la rehabilitación del maxilar severamente atrofiado: una revisión de la literatura. Int. J. Med. Surg. Sci., 3(1):771-777, 2016.

RESUMEN: La reabsorción severa en sectores posteriores del maxilar, como resultado de la pérdida de dientes junto con el proceso de neumatización del seno maxilar, resulta en una difícil rehabilitación protésica con el apoyo de los implantes convencionales, debido a la escasez de hueso vertical disponible. A lo largo de los años se han diseñado alternativas terapéuticas para ayudar a superar estos inconvenientes. El implante cigomático fue introducido en 1988 por Branemark. Este implante tiene un diseño que permite colocarse sobre la cresta hasta la altura del primer molar, reduciendo el voladizo bucal hasta en un $20 \%$, con la consecuente reducción de las complicaciones del peri-implantarias, como inflamación, infección y la hiperplasia gingival, que pueden conducir al desarrollo del proceso de perforación horizontal del hueso palatino. El propósito de esta revisión fue determinar la tasa de éxito de los implantes cigomáticos para la rehabilitación del maxilar gravemente atrófico. Un total de 1410 implantes cigomáticos y 1673 implantes tradicionales fueron descritos en los artículos seleccionados. De estos 1410 implantes cigomáticos, 365 eran de carga convencional y 1045 fueron de carga inmediata y temprana, teniendo una tasa de éxito del $98,3 \%$ y 98,7\%, respectivamente. De los 1673 implantes tradicionales, 463 fueron de carga convencional y 1210 fueron de carga inmediata y temprana, presentando una tasa de éxito del $93,9 \%$ y $97,8 \%$, respectivamente. La tasa de éxito de los implantes cigomáticos y los implantes convencionales fue del $98,6 \%$ y $96,8 \%$, respectivamente. La rehabilitación del maxilar severamente atrofiado con prótesis fija convencional cargado inmediatamente y por los implantes cigomáticos otorgó excelentes resultados en el mediano plazo. Al comparar las modalidades de tratamiento tradicionales, propuestas para la reconstrucción protésica del maxilar severamente atrofiado, el implante cigomático tiene la mayor tasa de éxito respecto a los tratamientos convencionales.

PALABRAS CLAVE: Implantes cigomáticos; Tasa de éxito; Maxilar desdentado; Maxilar reabsorbido; Maxilar atrofiado.

\section{REFERENCES}

Ahlgren, F.; Størksen, K. \& Tornes, K. A study of 25 zygomatic dental implants with 11 to 49 months' follow-up after loading. Int. J. Oral Maxillofac. Implants, 21(3):421-5, 2006.

Aparicio, C.; Ouazzani, W.; Aparicio, A.; Fortes, V.; Muela, R.; Pascual, A.; Codesal, M.; Barluenga, N. \& Franch, M. Immediate/Early loading of zygomatic implants: clinical experiences after 2 to 5 years of follow-up. Clin. Implant Dent. Relat. Res., 12 Suppl. 1:e77-82, 2010.

Aparicio, C.; Ouazzani, W.; Garcia, R.; Arevalo, X.; Muela, R. \& Fortes, V. A prospective clinical study on titanium implants in the zygomatic arch for prosthetic rehabilitation of the atrophic edentulous maxilla with a follow-up of 6 months to 5 years. Clin. Implant Dent. Relat. Res., 8(3):114-22, 2006.

Balshi, S. F.; Wolfinger, G. J. \& Balshi, T. J. A retrospective analysis of 110 zygomatic implants in a single-stage immediate loading protocol. Int. J. Oral Maxillofac. Implants., 24(2):335-41, 2009.

Becktor, J. P.; Isaksson, S.; Abrahamsson, P. \& Sennerby, L. Evaluation of 31 zygomatic implants and 74 regular dental implants used in 16 patients for prosthetic reconstruction of the atrophic maxilla with cross-arch fixed bridges. Clin. Implant Dent. Relat. Res., 7(3):159-65, 2005. 
Bedrossian, E.; Rangert, B.; Stumpel, L. \& Indresano, T. Immediate function with the zygomatic implant: a graftless solution for the patient with mild to advanced atrophy of the maxilla. Int. J. Oral Maxillofac. Implants, 21(6):987-42, 2006.

Bedrossian, E.; Stumpel, L. 3rd; Beckley, M. L. \& Indresano, $\mathrm{T}$. The zygomatic implant: preliminary data on treatment of severely resorbed maxillae. A clinical report. Int. J. Oral Maxillofac. Implants, 17(6):861-5, 2002.

Butura, C. C. \& Galindo, D. F. Combined immediate loading of zygomatic and mandibular implants: a preliminary 2-year report of 19 patients. Int. J. Oral Maxillofac. Implants, 29(1):e22-9, 2014.

Carvajal, J. C.; Von Martens, A. \& Leighton, Y. Función oclusal inmediata con implantes zigomáticos en maxilares severamente reabsorbidos. Rev. Clin. Periodoncia Implantol. Rehab. Oral, 2(3):137-42, 2009.

Chow, J.; Hui, E. ; Lee, P. K. \& Li, W. Zygomatic implants-protocol for immediate occlusal loading: a preliminary report. J. Oral Maxillofac. Surg., 64(5):804-11, 2006.

Davó, R. Zygomatic implants placed with a two-stage procedure: a 5-year retrospective study. Eur. J. Oral Implantol., 2(2):115-24, 2009.

Davó, R.; Malevez, C. \& Pons, O. Immediately loaded zygomatic implants: a 5-year prospective study. Eur. J. Oral Implantol., 6(1):39-47, 2013.

Davó, R.; Malevez, C. ; Rojas, J.; Rodríguez, J. \& Regolf, J. Clinical outcome of 42 patients treated with 81 immediately loaded zygomatic implants: a 12- to 42-month retrospective study. Eur. J. Oral Implantol., 1(2): 141-50, 2008.

Degidi, M.; Nardi, D.; Piattelli, A. \& Malevez, C. Immediate loading of zygomatic implants using the intraoral welding technique: a 12-month case series. Int. J. Periodontics Restorative Dent., 32(5):e154-61, 2012.

Hirsch, J. M.; Ohrnell, L. O.; Henry, P. J.; Andreasson, L.; Brånemark, P. I.; Chiapasco, M.; Gynther, G.; Finne, K.; Higuchi, K. W.; Isaksson, S.; Kahnberg, K. E.; Malevez, C.; Neukam, F. W. ; Sevetz, E.; Urgell, J. P.; Widmark, G. \& Bolind, P. A clinical evaluation of the Zygoma fixture: one year of followup at 16 clinics. J. Oral Maxillofac. Surg., 62(9 Suppl. 2):22-9, 2004.

Kahnberg, K. E.; Henry, P. J.; Hirsch, J. M.; Ohrnell, L. O.; Andreasson, L.; Brånemark, P. I.; Chiapasco,
M.; Gynther, G.; Finne, K.; Higuchi, K. W. ; Isaksson, S.; Malevez, C.; Neukam, F. W.; Sevetz, E. Jr.; Urgell, J. P.; Widmark, G. \& Bolind, P. Clinical evaluation of the zygoma implant: 3-year followup at 16 clinics. J. Oral Maxillofac. Surg., 65(10):2033-8, 2007.

Klurfan, F. J. \& Klurfan, C. N. Tratamiento de atrofias maxilares con implantes cigomaticos como alternativa al relleno de seno maxilar. Rev. Asoc. Odontol. Argent., 96(5):447-51, 2008.

Malevez, C.; Abarca, M.; Durdu, F. \& Daelemans, P. Clinical outcome of 103 consecutive zygomatic implants: a 6-48 months follow-up study. Clin. Oral Implants Res., 15(1):18-22, 2004.

Maló, P.; Nobre, Md.; Lopes, A.; Francischone, C. \& Rigolizzo, M. Three-year outcome of a retrospective cohort study on the rehabilitation of completely edentulous atrophic maxillae with immediately loaded extra-maxillary zygomatic implants. Eur. J. Oral Implantol., 5(1):37-46, 2012.

Migliorança, R. M.; Coppedê, A.; Dias Rezende, R. C. \& de Mayo, T. Restoration of the edentulous maxilla using extrasinus zygomatic implants combined with anterior conventional implants: a retrospective study. Int. J. Oral Maxillofac. Implants, 26(3):66572, 2011.

Mozzati, M.; Monfrin, S. B.; Pedretti, G. ; Schierano, G. \& Bassi, F. Immediate loading of maxillary fixed prostheses retained by zygomatic and conventional implants: 24-month preliminary data for a series of clinical case reports. Int. J. Oral Maxillofac. Implants, 23(2):308-14, 2008.

Nakai, H.; Okazaki, Y. \& Ueda, M. Clinical application of zygomatic implants for rehabilitation of the severely resorbed maxilla: a clinical report. Int. J. Oral Maxillofac. Implants, 18(4):566-70, 2003.

Peñarrocha, M.; García, B.; Martí, E. \& Boronat, A. Rehabilitation of severely atrophic maxillae with fixed implant-supported prostheses using zygomatic implants placed using the sinus slot technique: clinical report on a series of 21 patients. Int. J. Oral Maxillofac. Implants, 22(4):645-50, 2007.

Correspondence to:

Felipe Alejandro Cid Cisternas

Los Camperos \#1735

Temuco

Región de la Araucanía CHILE

Received: $30-10-2015$ Accepted: 26-12-2015

Email: f.cid.cisternas@gmail.com 